\title{
AN INVESTIGATIVE STUDY OF THE ROLE OF SANTHIKARMA IN MENTAL HEALTH
}

\author{
J. K. A. Kanthi ${ }^{1 \rrbracket}$ (iD) \\ ${ }^{1}$ Senior Lecturer, Department of History and Archaeology, University of Ruhuna, Matara Sri Lanka.
}

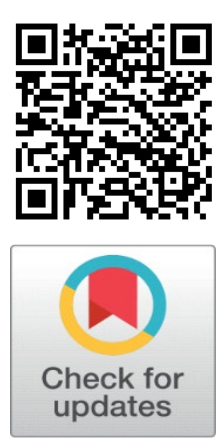

Received 18 October 2021

Accepted 18 November 2021

Published 30 November 2021

\section{CorrespondingAuthor}

J. K. A. Kanthi, jkanthi@hist.ruh.ac.lk

DOI

10.29121/granthaalayah.v9.i11.2021 .4365

Funding: This research received no specific grant from any funding agency in the public, commercial, or not-for-profit sectors.

Copyright: (C) 2021 The Author(s). This is an open access article distributed under the terms of the Creative Commons Attribution License, which permits unrestricted use, distribution, and reproduction in any medium, provided the original author and source are credited.

\section{ABSTRACT}

Several areas reflect the traditional wisdom of Sri Lanka. This knowledge is of two parts as tactile and intangible cognition. Shantikarma and its associated rituals have a special place in intangible knowledge. Humans rely on various supernatural forces to prevent them from suffering and suffering. The medium used to obtain the help of those forces is called Shanti Karma. Several areas reflect the traditional wisdom of Sri Lanka. This knowledge is of two parts as tactile and intangible cognition. Shantikarma and its associated rituals have a special place in intangible knowledge. Humans rely on various supernatural forces to prevent them from suffering and suffering. The medium used to obtain the help of those forces is called Shanti Karma. The research problem was how Shanti Karma is used as an art of healing. The methodology involved in this research was Qualitative and Quantitative. Data were gathered using primary and secondary evidence in-depth interviews. A sample of about 20 yakaduras from Palatuwa, Godagama in Matara District, Habaraduwa and, Ahangama in Galle District was selected for the field study. The secondary evidence was the substance yielded from the published sources. Today, there is a decline in the use of peace rituals in Sri Lanka. The decline in the number of people willing to engage in this, the emergence of a new generation after the decline of traditional artisans, and the need to pay a high price for peacemaking, etc., have contributed to this decline.

Keywords: Shanthi Karma, Indigenous Knowledge, Psychological

\section{INTRODUCTION}

No matter how technologically advanced, if he finds himself in a catastrophic situation, his mind will naturally be drawn to the invisible forces he believes in. A man also believed that this occult power was often associated with divinity. Accordingly, they worshiped all the objects of nature, such as the sun, moon, trees, and leaves. All-natural phenomena in the environment, such as the sun, rain, and wind, have been attributed to life, and worship of nature has been around since ancient times, believing that life affects humans. At some point, a thunderstorm, a thunderstorm, a torrential downpour, or an illness or an injury or a severe heartache, the helpless man asked to be healed, remembering a god he had drawn in his heart. The form of a man who bows most pleasingly and kneels before the image in his heart is sometimes frightening and sometimes sad. The figure of this man praying with his hands raised to the sky and his head bowed on the ground is reminiscent of a play on the one hand. This form later evolved into a form of drama. It is possible that Shantikarma was born as a result of those worships. 


\section{METHOD}

This study did base on collecting data through a qualitative and Quantitative research methodology. Data were gathered using primary and secondary evidence in-depth interviews. A sample of about 15 yakaduras from Palatuwa, Godagama in Matara District, Habaraduwa and, Ahangama in Galle District in Sri Lanka was selected for the field study. Data analysis is based on the historical approach.

\section{RESULTS AND DISCUSSION}

The word shaantikarma means good action. Peace means calmness of body and mind. The person was cured of the disease by getting proper nutrition and getting rid of diseases. He gained peace of mind by fulfilling expectations and getting rid of troubles. If the environment in which one lives is productive and peaceful, it will provide an opportunity for a large community, not just an individual, to experience prosperity. Accordingly, pacifism was used by people from many different cultures worldwide to bring relief from various afflictions, from minor crises to large-scale chaos. Among the works collected by Hugh Nevil, who served in Sri Lanka as a public servant during British rule, were several books on pacifism Daraniyagala. (1954).

There is a long-standing connection between pacifism and Sri Lankan society. Pacifism has been used in Sri Lankan society for centuries. The Kohomba Kankariya performed by King Panduwasadeva (5th century BC), who was frightened by a nightmare, is the first recorded ritual in Sri Lanka. Thus, various peace ceremonies are performed at different times. Bail binding to avoid fever and headache, Seth poem sung for some good, Pattini pooja for children, Chem and Gam Pirith for the protection of farmers and livestock, etc. Coconut fighting for the common good of the village New Year festivities are examples of Sri Lankan culture. Pacifism is largely confined to one caste. But the witches in the Sabaragamuwa Province are not limited to one caste. (Vitharana, 1992: 30)

There are three traditions of peace rituals in Sri Lanka that can be considered as local art. These are the Kandyan Tradition, Low Country Tradition, Ruhuna Tradition, and Sabaragamuwa Tradition. These differ from each other in singing, playing, and acting style. There are also differences in dress and grooming. The songs used in the rituals are often based on devotion to the Triple Gem and belief in demons. The language of these songs is very simple. However, some hymns are a mixture of Sanskrit and Malayalam and are sung in very loud and clear voices as worship stanzas and verses or octaves. The tone patterns used there are sometimes extremely simple. Sometimes complex. This whole style of singing attracts the audience as well as the sick. Looking at the history of Sri Lankan Shanti Karma, it is clear that the Sinhala Buddhist people have tried to perform Shanti Karma as a Buddhist ritual by adding a Buddhist face to the ancient rituals. (. (Vitharana, 1992: 7))

With the advancement of modern psychology, medicine and sociology, the traditional healing arts that have been around for a long time in many parts of the world are slowly disappearing. With the advancement of Western medicine, this may result from the rejection of traditional healing techniques. However, a careful study of these strategies confirms that they knew certain modern and abnormal psychology areas.

According to traditional pacifications, the patient's mind is specially prepared before the treatment. Accordingly, the sick person should abstain from meat. After bathing and cleansing, a white cloth is wrapped from head to toe, and a lamp is taken 
by hand and brought to the Athura Pandala. In doing so, he hoped to instill in his mind that he was a special person. Before sitting on the Athura Pandala, Yakeduru utters a statement that enters his mind that this pacification will heal him. The sheath is then placed in front of the shelf, which is lined with porridge. The floor is covered with a blanket so that the patient can hear the sound of drums and chanting. The patient then removes the covered veil as the flame rises by chewing gum. At the same time, the patient's fear disappears after some fear of what they have not seen and heard. He feels that the demons that have destroyed him are gone. The patient is then enlightened by the dances and theatrical dialogues that follow. (Jayasena, Low Country Peace Literature 262263 pages). The pacifist dances are also designed to use special techniques to cure patients suffering from phobias or anxiety. The 18 communications in the low country pacifist tradition are designed to resemble the methodology of sequential dissociation used to dispel the fears or anxious thoughts of modern abnormal psychology. Each style of acting and the masks and costumes used are used to heal the patient in a very systematic manner. Although the masks worn in the beginning seemed a bit pleasing, the grim look on those faces continues to increase step by step. In doing so, they hope to try to eliminate anxiety systematically. Eventually, he takes a scary mask and rushes to the bed. But by then, the onlooker's fears were gone. This means that the sick person is healed. Similar features can be seen in peace rituals such as Devolmaduwa and Riddiyaga and the rituals associated with the Kohombakankariya, Graha Shanthi, and Goddess Pattini found in the Kandyan tradition.

The decorations used in the peace ceremonies also attract the attention of the visitors. They are designed for psychotherapy. Sacrifices or sheds are made using pure coconut leaves, banana leaves or leaves, varieties, and various types of pottery, decorated with very colorful colors and carvings. Doing so promotes the devotion and mental concentration of those involved.

In counseling psychology, which has developed as a branch of modern psychology, there are also successful methods that can be used for any abnormal behaviors. It is questionable whether there is any similarity between counseling approaches for disaster victims and pacification. There are several ways in which catastrophic mood swings can affect individuals. Some are caused by natural disasters such as floods, tsunamis, hurricanes, earthquakes, landslides, thunderstorms, and fires. Some disasters are caused by humans. Examples include physical torture, abduction, aggravated assault, involvement in war riots, and car accidents. When one considers the victims of such catastrophes, one finds that the person is terrified and that the horrible thought or event that has taken place is often recalled and anxious. Another feature is the inability of the individual to return to normalcy without the help of an outside party. What happened in the past was that a solution to this situation could be found through peacemaking. In this case, it appears that the pacifists of the past cured the same ailments that are known to be present in modern-day victims. The use of Shantikarma among the Sri Lankan people for such a long time confirms its success as psychotherapy. Psalms are used for various abnormal behaviors such as depression, anxiety, phobia, mental disorders, sexual problems, and personality problems. They understood man's needs according to the prevailing beliefs and pretended to be peacemakers as a special remedy for the mind. It was not just the virtue of peace that brought peace to society through pacifism. In pacifism, the practice of preserving the ethics and caste customs that contribute to the immutability of the culture of a country or a society and the ill effects of violating them peacefully takes place. This was intended to assert that man should live on social justice. The Genesis story of the Sorcery Sacrifice results from a breach of the promise made by the Great Standard Dynasty. The birth of the Sunny Devil was due to the evil human feelings of gossip and 
revenge. The birth of Mahason made it clear that incestuous marriage and illicit sex should be removed from society.

Shantikarma provides mental health, spiritual cultivation, and the background needed to overcome the thousands of shortcomings and weaknesses that occur in human life. The Riddi Yaga is the best example of this. Riddiyaga is a beautiful illustration of how a couple who are childless without a good marital relationship should have a child. Also, Sri Lankans called the depressive psychological condition of unmarried girls captivated by sexual impulses Kalukumara Dishtiya. Sri Lankans had the understanding to satisfy those sexual urges by doing a pacification for this mental disorder. This stress is reduced by relaxing the body through activities such as listening to drums and dancing to drums. Realizing the need to eliminate this situation, the parents are tempted to arrange a suitable marriage. Thus, the myths and legends of the birth of Yaksha Deva, which are the backdrop for the peace rituals that are carried out for the good of the worldly life, clearly reflect the intellectual nature of the peace rituals, which is capable of purifying the society.

Before introducing modern psychological counseling methods, individuals with abnormal behaviors were expelled from society in European countries. Still, the ancient Sri Lankans cured such individuals by pacification and kept them around. Also, a by-product of Shruti Karma is the union of family and friends and social coexistence through Shanti Karma. Most important is to establish in society the attitude that the person being subjected to pacification is no longer a patient.

The counseling methods developed with the advancement of Western medicine have been passed down through the centuries as various pacifists in the East. Especially in Sri Lanka, this pacifist literature was used by everyone to heal their minds, from the ruler to the general public. Sedaraman (1964). Some decline can be seen today. The decline of the traditional generation of artisans, the reluctance of the present generation to acquire such craftsmanship, the lack of royal patronage or another patronage, and the over-reliance on Western medical treatment have all contributed to this decline.

\section{CONCLUSION}

Peace rituals have a special place as a major feature of Sri Lanka's heritage. It is clear that this was inspired by India, but they have gradually developed into a local identity. Sacrifices are a natural part of every human being in the world. They believed that there was something mysterious about the natural objects in their environment. They were worshiped, thinking that the occult had an invisible power. These conditions gradually developed and became cultural elements. That is how the peace process in Sri Lanka began. The people later believed that the gods who led them were demons and ghosts. Of the 33 million deities mentioned in the religious literature, various beliefs about the gods are prevalent among the people. These gods are believed to teach people good as well as bad. There are similar ideas about demons. Shantikarma is used as a means of offering sacrifices to all these forces. Many of the offerings associated with local agriculture and other industries are associated with pacifism. It also has a systematic structure and form that heals the hurt mind. However, the decline of peacemaking in Sri Lanka today can be described as detrimental to Sri Lankan culture. Therefore, the creators of Shantikarma should not be dismissed as ignorant. Shantikarma literature should also be further refined and reaped its results. 


\section{REFERENCES}

Daraniyagala P.E.P. (ed). (1954) Verse I. Colombo.

Kottagoda, J, (1995). Sabaragamu Kirimadu Shantikarma Daluwattha. Printers: Colombo.

Kottagoda, J. (2003). pahatharataShanthikarma Sahithya. Colombo.

Paranavithana.S. (1970). Inscription of Ceylon. Colombo.

Rajapaksha,S. (2000). Sabaragamu Kumara Samayama .S.Godage publication: Colombo

Sannasgala.P.B. (1961). Sinhala Sahithya wansaya. Colombo.

Sarananda (ed). (1931).Saddharmalankaraya. Colombo

Sedaraman .J.E. (1964). Lankawe Bali Upatha. Colombo.

Sedaraman .J.E. (1967). Bali yaga vicharaya. Colombo.

Sri Sumangala, Hikkaduwe. Batuwanthudawe Don Andrias de Silva: (Trans) (1912).

Mahavamsa, the Museum Department: Colombo. 